\title{
Effect of Delay in Postpartum Hemorrhage Management on the Rate of Near-Miss and Maternal Death Cases
}

\section{Pengaruh Keterlambatan Penanganan Perdarahan Pascapersalinan terhadap Kejadian Hampir Mati dan Kematian Ibu}

\author{
Risanto Siswosudarmo \\ Division of Social Obstetrics and Gynecology \\ Department of Obstetrics and Gynecology \\ Faculty of Medicine University of Gadjah Mada/ \\ Dr. Sardjito Hospital \\ Yogyakarta
}

\begin{abstract}
Objective: To recognize the effect of delay in the management of postpartum bleeding to the occurrence of near-miss and maternal death cases.

Method: Prospective cohort. The study population was patients with postpartum hemorrhage. All PPH cases from thirteen hospitals (Sardjito and 12 affiliated hospitals) were recorded. The study was carried out from January 1 st to June 30 th 2009 . The study group was those who experienced delay and the control group was those without delay. The outcome was measured as the number of near-miss and death cases. Near-miss was defined as those who experienced severe shock, demonstrated by systolic blood pressure $90 \mathrm{mmHg}$ or less. Chi square test, t-test and logistic regressions were used to analyze our data.
\end{abstract}

Result: From January $1^{\text {st }}$ to June $30^{\text {th }} 2009$ we identified 139 cases of PPH from 8,924 deliveries (1.6\%). From the 80 referred cases, as much as 22 cases $(27.5 \%)$ were delayed, and 12 from $139(8.6 \%)$ experienced delay in the hospital. A total of 30 cases among 139 $(21.6 \%)$ experienced delay both outside and in the hospital. There were 74 near-miss cases, 9 of which ended in death of the patient. This means the real occurrence of near-miss cases is 65 from 139 cases or $46.8 \%$ while the occurrence of maternal death was 9 out of 139 , or $6.47 \%$. Case fatality rate was 9 from 139 or $6.47 \%$; maternal near-miss ratio was 6.22 ; mortality index was $13.84 \%$ and maternal mortality ratio is estimated as $103 / 100.000$ live births. Multivariate analysis showed delay in referral increased the risk of near-miss cases as much as 8.37 folds, while bleeding $>1500 \mathrm{ml}$ increased risk of near-miss by 12.12 folds. Delay in both referral and management in the hospital increased the risk of maternal death rate as much as 25.34 folds, hemoglobin $<6 \mathrm{~g} / \mathrm{dl}$ and unavailability of blood increase maternal death by 31.58 folds and 13.39 folds, respectively.

Conclusion: Delay in referral and delay of in-hospital management increased the occurrence of near-miss and maternal mortality cases significantly. Multivariate analysis showed that the amount of bleeding, hemoglobin level and lack of blood availability influenced the occurrence of near-miss and maternal death more than the delay itself.

[Indones J Obstet Gynecol 2014; 4: 177-181]

Keywords: delay, maternal death, maternal near-miss, PPH

\begin{abstract}
Abstrak
Tujuan: Untuk mengetahui pengaruh keterlambatan penanganan perdarahan pascapersalinan (PPP) terhadap kasus kejadian hampir mati dan kematian ibu.

Metode: Rancangan yang dipakai adalah kohort prospektif. Populasi penelitian adalah para ibu yang mengalami perdarahan pascapersalinan. Dilakukan pencatatan semua kasus PPP pada tiga belas rumah sakit (RS Sardjito dan 12 RS afiliasi). Penelitian ini berlangsung sejak 1 Januari sampai dengan 30 Juni 2009. Kelompok studi adalah mereka yang mengalami keterlambatan penanganan sedang kelompok kontrol adalah yang tidak mengalami keterlambatan. Kejadian hampir mati dan kematian ibu adalah hasil utama yang diamati. Kejadian hampir mati adalah mereka yang mengalami syok berat yang tercermin dengan tekanan darah sistolik kurang dari $90 \mathrm{mmHg}$. Digunakan uji Chi square, t-test dan regresi logistik untuk mengolah data yang kami peroleh.

Hasil: Sejak 1 Januari sampai dengan 30 Juni 2009 terdapat 139 kasus PPP dari 8924 kelahiran $(1,6 \%)$. Dua puluh dua dari 80 kasus rujukan mengalami keterlambatan (27,5\%), sedangkan 12 dari 139 (8,6\%) mengalami keterlambatan penanganan di rumah sakit. Sebanyak 30 kasus dari $139(21,6 \%)$ mengalami keterlambatan baik di luar maupun di dalam rumah sakit. Kejadian hampir mati sebanyak 74 kasus, 9 di antaranya berakhir pada kematian. Dapat disimpulkan bahwa kejadian hampir mati yang sebenarnya adalah 65 dari 139 kasus atau 46,8\% sedangkan kasus kematian ibu adalah 9 dari 139, atau 6,47\%. Case fatality rate adalah 9 dari 139 atau 6,47\%; rasio maternal near-miss adalah 6,22; indeks mortalitas 13,84\% dan angka kematian ibu 103/100.000 kelahiran hidup. Analisis multivariat menunjukkan bahwa keterlambatan dalam rujukan menaikkan kejadian hampir mati sebanyak 8,37 kali, perdarahan $>1500 \mathrm{ml}$ meningkatkan kejadian hampir mati 12,12 kali. Kelambatan keduanya yakni rujukan dan penanganan di rumah sakit menaikkan risiko kematian ibu sebanyak 25,34 kali, sedangkan hemoglobin $<6 \mathrm{~g} /$ dl dan ketidaktersediaan darah meningkatkan kematian ibu masing-masing sebanyak 31,58 kali dan 13,39 kali.

Kesimpulan: Keterlambatan dalam rujukan dan penanganan di rumah sakit meningkatkan kejadian hampir mati dan kematian ibu secara signifikan. Analisis multivariate menunjukkan bahwa jumlah perdarahan, tingkat hemoglobin dan ketidaktersediaan darah lebih berpengaruh terhadap kejadian hampir mati dan kematian ibu dibanding keterlambatan sendiri.
\end{abstract}

[Maj Obstet Ginekol Indones 2014; 4: 177-181]

Kata kunci: kejadian hampir mati, kematian ibu, keterlambatan, PPP

Correspondence: Risanto Siswosudarmo. Department of Obstetrics and Gynecology, Faculty of Medicine University of Gadjah Mada, Yogyakarta. Telephone: 081229696 22; Email:hrisanto@yahoo.com 


\section{INTRODUCTION}

Maternal mortality rate (MMR) is one indicator to assess the success of health development, especially in the field of maternity and reproductive health service. According to the Indonesian Health Demographic Survey carried out in 2003, the MMR of Indonesia was 307/100,000 live births, while in 2007 it was 228/100,000 live births. ${ }^{1}$ Millennium development goal has targeted that by the end of 2015 Indonesia should have an MMR of 102/ 100,000 live births.

The most common cause of maternal death in developing countries, including Indonesia, is hemorrhage. ${ }^{2}$ Data from Dr. Sardjito Hospital demonstrated that hemorrhage was responsible $22.6 \%$ of maternal death ${ }^{3}$ while in the Province of Yogyakarta, hemorrhage was responsible for $29 \%$ of maternal death. ${ }^{4}$ Maternal death due to hemorrhage should not occur if three conditions are fulfilled, namely no delay in the management, presence of skilled medical personnel and medical equipment and adequate blood availability. Delay in the management of hemorrhage might also be influenced by factors such as failure in recognizing the disease (risk factors, signs and symptoms), delay in the referral system and delay in the tertiary health facilities.

The objective of the present study was to find out the influence of delay in the management of postpartum hemorrhage on the occurrence of near-miss and death cases at Dr. Sardjito hospital and its affiliated hospitals.

\section{METHOD}

The prospective cohort study was carried out in Dr. Sardjito hospital and 12 affiliated hospitals in the province of Special Region of Yogyakarta and Central Java, from $1^{\text {st }}$ of January to $30^{\text {th }}$ of June 2012. The main factor studied was delay in management, either delay in recognizing the disease or deciding to refer, delay in the referral process or delay at the referral hospital. As it was very difficult to identify the exact reason of delays outside the hospital, we divided delays into two categories. The first was delay before arriving at the hospital and the second one is delay during management at the hospital. The first delay was defined as referral time more than 3 hours. The second delay was defined if one of the following conditions is fulfilled: delay during consultation that took more than one hour to get a definitive treatment, response time of operating theatre of more than one hour, and not enough blood as needed to replace blood loss.

All cases with the diagnosis of postpartum hemorrhage, both referred cases or those who gave birth at the hospital were included. Postpartum hemorrhage was defined as bleeding $500 \mathrm{ml}$ or more for vaginal and $1000 \mathrm{ml}$ or more for cesarean deliveries. ${ }^{5}$ Assessment was done by the resident in charge supervised by a senior resident. Ethical clearance and letter of permission from the Director of Hospitals and District Authorities were obtained before this study was initiated. Informed consent was obtained before recruitment into the study.

The main outcome was near-miss and death cases. Near-miss cases in this study was defined as a condition that met one of the following criteria: severe shock as indicated by blood pressure $<90 / 60 \mathrm{mmHg}$, pulse rate $>100 /$ minute, respiratory rate $>30 /$ minute, urine output $<30 \mathrm{ml} /$ hour, blood transfusion $1250 \mathrm{ml}$ (5 packs of blood), needing care in the intensive care unit (ICU), and requiring major operation to stop the hemorrhage by either hysterectomy or B-Lynch suture.

Data were recorded using specially designed forms for computer analysis. Data analysis was carried out using SPSS software. Chi-square test, t-test, and logistic regression were used for statistical analysis. A p value of less then 0.05 was used to demonstrate statistical significance.

\section{RESULT AND DISCUSSION}

From January $1^{\text {st }}$ to June $30^{\text {th }} 2009$ there were 139 postpartum hemorrhage cases among the 13 hospitals, $18 \%$ at Dr. Sardjito hospital and $88 \%$ at affiliated hospitals. The incidence of PPH in this study was $1.6 \%$, which seemed small compared to the finding of other authors, which was approximately $6 \%$ for vaginal delivery and $8 \%$ for cesarean section. ${ }^{5}$ The higher incidence had also been reported by Ramanathan and Arulkaman ${ }^{6}$, which reached $5 \%$ to $15 \%$. Similar to our findings, low incidence of PPH was found in North India $(0.6 \%)^{7}$ and North Sumatra (1.4\%). ${ }^{8}$ This difference might be caused by difference in methods of measuring blood loss, which tends underestimate hemorrhage. In patients with overt bleeding, the attendants were likely to calculate the amount of blood loss more precisely. For referral cases, the amount of bleeding 
was not measurable. The mean blood loss in our study was $1287.7 \mathrm{ml} \quad 705.6 \mathrm{ml}$ and ranged from $600 \mathrm{ml}$ to $4000 \mathrm{ml}$.

Uterine atony was the main cause of bleeding (52.5\%), which proved to not be different from other studies. ${ }^{5,9}$ Other causes include retained placenta and placental fragment, birth canal laceration, and we also encountered 5 cases of uterine rupture $(3.6 \%)$.

Table 1. Characteristic of Cases

\begin{tabular}{|c|c|c|c|}
\hline No & Variable & $\mathbf{N}$ & Percentage \\
\hline \multicolumn{4}{|c|}{ 1. Delay outside hospital } \\
\hline & a. No & 58 & 72.5 \\
\hline & b. Yes & 22 & 27.5 \\
\hline \multicolumn{4}{|c|}{ 2. Delay inside hospital } \\
\hline & a. No & 127 & 91.4 \\
\hline & b. Yes & 12 & 8.6 \\
\hline \multicolumn{4}{|c|}{3 Both delays } \\
\hline & a. No & 109 & 78.4 \\
\hline & b. Yes & 30 & 21.6 \\
\hline \multicolumn{4}{|c|}{4 Referral case } \\
\hline & a. No & 59 & 42.4 \\
\hline & b. Yes & 80 & 57.6 \\
\hline \multicolumn{4}{|c|}{5 Type of delivery } \\
\hline & a. Cesarean section & 43 & 30.9 \\
\hline & b. Vaginal & 96 & 69.1 \\
\hline
\end{tabular}

The mean age of the study subjects in this study was 312.37 years old. There was no significant difference between those who experienced delay (30.90 6.34 years) and who did not (31.20 6.91 years). No significant difference was identified in terms of parity, education, and social-economic factors.
The mean referral time in this study was 2.17 hours, ranging between 0.5 to 5.5 hours. We defined delay in this study when referral time exceeded 3 hours. Delay in the management of PPH is one of the main causes of maternal death. In this study, we classified the delay into two groups, namely delay outside the hospital (referral delay) and delay inside the hospital. Type of delays and characteristics of cases are shown in Table 1.

As much as $21.6 \%$ of cases underwent delay in the management of $\mathrm{PPH}$, consisting of $27.6 \%$ referral delay (22 out of 80 referral cases) and $8.6 \%$ delay inside the hospital (12 out of 139 cases).

Delay in the hospital, which ideally should not happen, might be attributable to some factors. They might be delayed during consultation because of multilevel examination from junior to senior residents before being presented to the consultant in charge. Another factor might be the operating theatre not being ready, especially outside working hours. In some hospitals, the anesthesiologist was not available. The solution to this is for all regency hospitals to have an anesthesiologist and other specialists who deal with obstetric emergencies standby at the emergency room for 24 hours.

There were 9 cases of maternal death among $139 \mathrm{PPH}$ cases, making the case fatality rate to be $6.5 \%$. There were 30 cases of delays occurring both outside and inside the hospital (21.6\%). Table 2 showed the effect of delay and other prognostic factors on the rate of near-miss cases or maternal death.

The effect of delay was more significant on the rate of maternal death compared to the near-miss cases. It was shown that the rate of maternal death due to delay outside hospital was increased 5.27 times, while the increase due to delay inside the hospital was 13.23 times, and if both delays happened together then the risk of maternal death was

Table 2. Prognostic Factors for Maternal Near-Miss and Maternal Death

\begin{tabular}{|c|c|c|c|c|}
\hline \multirow{2}{*}{ Prognostic factors } & \multicolumn{2}{|c|}{ Maternal near-miss } & \multicolumn{2}{|c|}{ Maternal Death } \\
\hline & RR (95\% CI) & p Value & RR (95\% CI) & p Value \\
\hline Delay & $1.44(0.98-2.11)$ & 0.06 & $12.72(3.45-46.91)$ & 0.004 \\
\hline Bleeding $1500 \mathrm{ml}$ & $2.15(1.56-2.98)$ & 0.003 & 4.18 (1.02-17.12) & 0.046 \\
\hline Hemoglobin <6g/dl & $2.10(1.53-2.97)$ & 0.02 & 8.21 (1.82-33.25) & 0.04 \\
\hline
\end{tabular}


12.72 times greater. It meant that prompt and accurate management in the hospital plays a great part in saving mothers.

Another factor contributing to the rate of nearmiss and maternal death was the amount of bleeding as shown on Table 2. As the hemoglobin level upon arrival may also represent the amount of bleeding, we attempted to study the association between hemoglobin content upon arrival and the rate of near-miss and maternal death. Hemoglobin content of less than $6 \mathrm{~g} / \mathrm{dl}$ increased the rate of near-miss cases as well as maternal death significantly (Table 2).

From the above analysis it was shown that delay, amount of bleeding and hemoglobin level upon arrival plays an important role in influencing the rate of near-miss and maternal death events. Multivariate analysis showed that the factors having the most dominant contribution on the occurrence of near-miss cases were delay, amount of bleeding and hemoglobin level upon arrival. Factors contributing to the occurrence of maternal death were delay, hemoglobin level and blood availability (Table 3).

The difference in rate of near-miss events in many literatures can be attributed to difference in definitions. In general, near-miss is defined as a condition necessitating accurate and prompt treatment to avoid death. 5,10 In this study, we took one important point such as profound shock characterized by a systolic blood pressure $90 \mathrm{mmHg}$ and/or bleeding $1500 \mathrm{ml}$, hemoglobin concentration $6 \mathrm{~g} / \mathrm{dl}$, intensive unit care (ICU) requirement, blood transfusion $1500 \mathrm{ml}$, need for hysterectomy, and occurrence of disseminated intravascular coagulation. By this definition, we found the rate of near-miss due to PPH to be 65 out of 139 cases (66.8\%). Using another definition, a study con- ducted in Banten province showed the rate of nearmiss cases to be $13.5 \%$. The rate of near-miss in the government hospital was $17.3 \%$ compared to $4.2 \%$ in the private hospital. ${ }^{11}$

Based on the above finding, some morbidity and mortality measurements can be calculated. The case fatality rate in this study was $9 / 139$ or $6.47 \%$. This number seemed to be lower than the $11.7 \%$ reported in North India, which also represents a developing country. ${ }^{7}$ The number of maternal death in this study was 9 out of 8,728 live births, giving a maternal mortality ratio due to $\mathrm{PPH}$ of 103 per 100,000 live births. This was also lower compared to that reported in North India, which was 1049 per 100,000 live births. ${ }^{7}$ Maternal near-miss ratio is the ratio between maternal near-miss to maternal death, which reflects the number of maternal near-miss for 1 maternal death. In this study, the maternal near-miss ratio is 6.22 . Another measurement is mortality index, representing the number of maternal death divided by the number of near miss cases. We found the mortality index in this study to be $9 / 65$ or $13.84 \%$. A greater maternal near-miss ratio or a smaller mortality index represents the success of maternal care services. ${ }^{10}$

The rate of near-miss in delayed referral cases was $81.8 \%$, while the death rate was $18.2 \%$. Delay for more then 3 hours increases the risk for nearmiss occurrence by 1.58 folds ( $95 \% \mathrm{CI}=1.05-2.38)$ and maternal death by 5.27 folds $(95 \% \mathrm{CI}=0.83$ 33.63). A similar study conducted in North Sumatra found one death among 60 cases $(1.67 \%)$ if the delay was more than 2 hours and a total of 2 maternal death occurrences out of 192 cases $(1.04 \%)^{8}$

As delay at the level of tertiary hospital still occurs, we suggest the development of a team or task force to overcome maternal-perinatal emergencies

Table 3. Logistic Regression Showing the most Common Variables Contributing to Maternal Near-Miss and Maternal Death

\begin{tabular}{lcccc}
\hline \hline \multirow{2}{*}{ Prognostic factors } & \multicolumn{2}{c}{ Maternal near-miss } & \multicolumn{2}{c}{ Maternal Death } \\
\cline { 2 - 5 } & OR (95\% CI) & p Value & OR (95\% CI) & p Value \\
\hline Delay & $8.37(1.30-67.80)$ & 0.04 & $25.34(3.11-206.01)$ & 0.002 \\
Bleeding $1500 \mathrm{ml}$ & $11.52(2.23-59.55)$ & 0.004 & - & - \\
Hemoglobin $6 \mathrm{~g} / \mathrm{dl}$ & $8.52(2.22-33.62)$ & 0.002 & $31.58(2.62-379.88)$ & 0.007 \\
Blood Availability & - & - & $13.39(1.38-129.39)$ & 0.02 \\
\hline \hline
\end{tabular}


under direct supervision from the vice director for medical service. This team should consist of at least an obstetrician, pediatrician, anesthesiologist, clinical pathologist, blood bank worker and operating theater team. The obstetrician would be the case manager to coordinate and determine the plan of action to save both mother and infant. This team also has to formulate a protocol for the management of obstetric and neonatal emergency. We would like to emphasize that during emergency situations, patients must be handled by a specialist team instead of residents. With this approach, we hope to minimize maternal and neonatal morbidity and mortality.

\section{CONCLUSION}

The incidence of PPH at Dr. Sardjito hospital and affiliated hospitals during the period of January $1^{\text {st }}$ to June $30^{\text {th }} 2009$ was $1.6 \%$ with uterine atony identified as the main cause. The rate of near-miss cases in this study was $46.8 \%$ and maternal death was $6.47 \%$. We found an MMR of 103 per 100,000 live births, case fatality rate of $6.47 \%$, maternal near-miss ratio of 6.22, and mortality index of $13.84 \%$. Delay played an important role for maternal death, but the hemoglobin level upon arrival and blood availability were more important in contributing to maternal death.

\section{REFERENCES}

1. Kusumobroto BS, Purwanto H, Hasnawati, et al. Profil Kesehatan Republik Indonesia 2007. Jakarta: Departemen Kesehatan RI; 2008.

2. WHO. The World Health Report. Make Every Mother and Child Count. Geneva: World Health Organization; 2005.

3. Wahyu 0, Siswosudarmo HR. Angka Kematian Maternal di RS Sardjito dalam Kurun Waktu 2003-2007. Presented at KOGI XVII. Balikpapan, 2008.

4. Siswosudarmo HR, Prawitasari S. Audit Maternal dan Perinatal Provinsi Daerah Istimewa Yogyakarta 2008. Presented at PIT Obstetri dan Ginekologi Sosial II. Palembang, 2009.

5. Cuningham FG, Leveno KJ, Bloom SL, et al. (eds.) Williams Obstetrics 23rd ed. New York: McGraw-Hill Medical; 2010: 759.

6. Ramanathan G, Arulkumaran S. Postpartum Hemorrhage. J Obstet Gynecol Can 2006; 28(11): 967-73.

7. Kaul V, Baga R, Jain V, et al. The impact of primary hemorrhage in near-miss morbidity and mortality in a tertiary hospital in North India. Ind J Med Sci 2008; 60(6): 233-40.

8. Nasution SA. Gambaran penanganan kasus kegawatdaruratan obstetrik di RS Tanjung Pura dan RS Kisaran, Kabupaten Asahan. Thesis. Universitas Sumatera Utara; 2003.

9. Maughan KL, Heim SW, Galazka SS. Preventing postpartum hemorrhage: managing the third stage of labor. Am Fam Physician 2006; 73: 1025-8.

10. Say L, Souza JP, Pattinson RC. Maternal near miss-towards a standard tool for monitoring quality of maternal health care. Best Prac Research Clin Obstet Gynecol 2009; 23: 28796.

11. Adisasmita A, Deviany PE, Nandiaty F, et al. Obstetric nearmiss and deaths in public and private hospitals in Indonesia. BMC Pregnancy Childbirth 2008; 8(10): 10. 